Рекомендована д. мед. наук, профр. К. А. Посоховою

УДК 615.451.1+582.929.3

DOI 10.11603/2312-0967.2016.3.6826

\title{
ОДЕРЖАННЯ І ДОСЛІДЖЕННЯ ВЛАСТИВОСТЕЙ ЕКСТРАКТІВ ВЕРБЕНИ ЛІКАРСЬКОї
}

\author{
(C) А. Р. Грицик, Н. М. Посацька, А. О. Клименко
}

ДВНЗ «Івано-Франківський національний медичний університет»

\begin{abstract}
Резюме: визначено гостру токсичність водного та водно-спиртового екстрактів трави вербени лікарської; досліджувані субстанції віднесено до V класу токсичності сполук за класифікацією Hodge та Sterner (практично нетоксичні речовини - $\mathrm{LD}_{50}>5000$ мг/кг). Доведено протизапальну активність водно-спиртового екстракту трави вербени лікарської. Досліджено вплив водного та водно-спиртового екстрактів трави вербени лікарської на біохімічні показники печінки при гострому експериментальному ураженні тетрахлорметаном. Екстракти трави вербени лікарської стабілізують мембранні структури клітин печінки, що свідчить про виражену гепатопротекторну активність.
\end{abstract}

Ключові слова: вербена лікарська, водний та водно-спиртовий екстракти.

Вступ. Важливим завданням фрармації $€$ пошук та створення нових лікарських засобів рослинного походження. Фітопрепарати характеризуються широким спектром фрармакологічної дії і малою токсичністю, що дозволяє використовувати їх тривалий час для профрілактики і лікування захворювань. Широке застосування лікарських рослин та препаратів на їх основі зумовлене наявністю в них різноманітних за хімічним складом і дією біологічно активних речовин, які мають здатність м'яко включатися в метаболізм і спричиняли мінімальну кількість побічних еоректів. Для фрлори України характерне різноманіття видового складу рослин. Особливої уваги заслуговують рослини 3 багатовіковим досвідом використання в народній медицині, до яких належать види роду Вербена [1, 2].
Зовнішні ознаки трави досліджуваного виду вербени представлені на рисунку 1.

Вербена лікарська широко розповсюджена на території України, проявляє протизапальну, антимікробну та гепатопротекторну дію [3, 4].

Отже, метою даних досліджень було одержання та визначення безпечності водного (ВЛТ-0) та водноспиртового (ВЛТ-7) екстрактів із трави вербени лікарської, встановлення фрармакологічної активності досліджуваних екстрактів.

Методи дослідження. Об'єктами дослідження обрано екстракти вербени (в.) лікарської (табл. 1).

На кафедрі фрармації Івано-Франківського національного медичного університету одержано екстракти $з$ досліджуваної сировини.

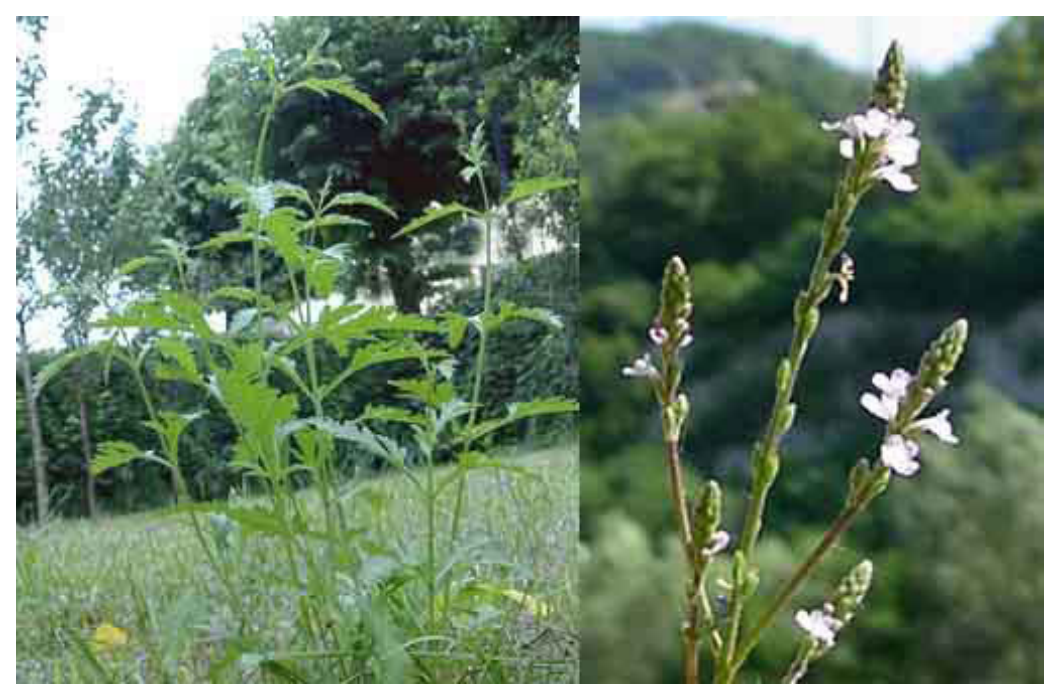

Рис. 1. Вербена лікарська.

ISSN 2312-0967. Pharmaceutical review. 2016. № 3 
Фармакологічні дослідження біологічно активних речовин Pharmacological researches of biologically active substances

Таблиця 1. Об'єкти дослідження

\begin{tabular}{|c|c|c|c|c|}
\hline $\begin{array}{c}\text { № } \\
\text { за/n }\end{array}$ & Лікарська рослина & Сировина & Вид екстрагенту & $\begin{array}{c}\text { Умовне } \\
\text { позначення }\end{array}$ \\
\hline 1 & \multirow{2nyyy}{*}{ Вербена (в.) лікарська } & Трава & Вода очищена & ВЛТ-0 \\
\cline { 1 - 4 } & & & $70 \%$ етанол & ВЛт-7 \\
\hline
\end{tabular}

Основним завданням подрібнення сировини можна вважати руйнування структури клітин і збільшення поверхні екстрагування $[5,6]$. Тип екстрагенту впливає не тільки на екстрагування певної групи речовин, але загальна кількість екстрактивних речовин залежить від гідрофрільності екстрагенту. Враховуючи, що в рослинах більшість речовин належить до гідрофрільних, полярні екстрагенти будуть екстрагувати більше екстрактивних речовин [6].

Спиртові витяжки з малим вмістом етанолу (40 \%) містять багато високомолекулярних сполук (водорозчинні білки, цукри, фрерменти, пектини, слиз, крохмаль), які повинні бути видалені [6].

Враховуючи хімічний склад трави вербени лікарської, як екстрагент було використано 70 \% етанол і воду очищену.

Вихідною сировиною для одержання екстрактів була висушена трава вербени (вологість 6 - 7 \%), подрібнена до розміру частинок 1 - 3 мм, яку заготовляли у 2014 році.

Для одержання водних екстрактів 200 г подрібненої рослинної сировини екстрагували 2,0 л води очищеної в колбі зі зворотним холодильником на киплячому водяному нагрівнику протягом 30 хв. Екстракт фрільтрували, а залишок сировини екстрагували в аналогічних умовах ще 2 рази. Витяжки фрільтрували і всі фрільтрати об'єднували.

Для одержання водно-спиртового екстракту трави 200 г подрібненої рослинної сировини екстрагували 200 мл 70 \% етанолом в колбі зі зворотним холодильником при температурі кипіння ектрагенту. Одержані витяжки об'єднували, етанол відганяли під вакуумом. Після відгонки етанолу загальний об'єм екстрактів доводили водою очищеною до початкового об'єму.

Водний і водно-спиртовий екстракти, одержані з трави вербени лікарської, розливали в стерильні фрлакони по 250 мл і піддавали ліофрільній сушці. Спочатку їх заморожували в спиртових ваннах при температурі спирту не вище $-40^{\circ} \mathrm{C}$ протягом 30 хв. Після цього фрлакони з замороженою витяжкою ставили в холодильник і при температурі не вище $-30{ }^{\circ} \mathrm{C}$ закалювали і зберігали перед загрузкою в сублімаційний апарат протягом 12 год. Сушіння витяжок проводили в сублімаційному апараті типу КС-30 (завод "Фрігера" Чехія). В початковому періоді роботи по сушінню знижували тиск в субліматорі від $1 \cdot 10^{-1}$ до $1 \cdot 10^{-5}$ мм рт. ст. і температуру заморожених витяжок до $+35-50{ }^{\circ} \mathrm{C}$. Через 2 - 2,5 год включали підігрів і через 12 - 16 год проводили постійне підвищення температури від мінусової до плюсової. Температура продукту в кінце- вому періоді висушування не перевищувала $+40^{\circ} \mathrm{C}$. Для одержання сухих екстрактів загальна тривалість сушіння має бути 28 - 32 год.

Одержані екстракти являють собою пухкі маси від світло-коричневого до коричнево-зеленого кольору зі специорічним запахом, гіркого смаку. Екстракти зберігають при температурі до $+5{ }^{\circ} \mathrm{C}$ в холодильнику або в сухому темному прохолодному місці в закритій тарі.

Вивчення біологічної активності та токсичності одержаних екстрактів проведено при консультаційній допомозі профресора кафедри фрармакології ІФНМУ Я. С. Гудивок та професора кафедри біологічної та медичної хімії імені акад. Г. О. Бабенка А. О. Клименка. Експериментальна робота виконана в об'ємі простого фрармакологічного скринінгу.

Експериментальні дослідження проводили на білих мишах і щурах, які знаходилися в умовах віварію відповідно до вимог санітарно-гігієнічних норм на стандартному раціоні [6].

Дослідження гострої токсичності екстрактів в. лікарської проводили за методикою О. В. Стефанова на безпородних білих мишах-самцях масою $20-24$ г [7].

Спостереження за тваринами здійснювали протягом 14 діб. Систематичну реєстрацію показників стану кожної тварини здійснювали не рідше одного разу на день.

Вивчення протизапальної активності екстрактів в. лікарської проводили на моделі набряку лапи щура, викликаного субплантарним введенням фрлогогенного агенту [7]. 3 цією метою під апоневроз підошви задньої лапи вводили 0,1 мл 2 \% водного розчину фрормаліну. Експериментальні дослідження проводили на білих щурах-самцях масою 0,20 - 0,22 г. Дослідження і аналіз отриманих експериментальних даних проводили порівняно із препаратом групи нестероїдних протизапальних засобів - диклосенаком.

Вимірювання об'єму лапи виконували до початку і в момент найбільшого розвитку набряку (5 год). За 2 год до введення орлогогенного агенту та відразу після цього тваринам перорально вводили досліджувані екстракти.

Вивчення гепатозахисної активності екстрактів в. лікарської проводили за методикою В. С. Позднякова і Н. Г. Иванова [8]. Досліди проводили на білих щурах-самцях масою 0,18 - 0,25 кг. Ураження печінки у тварин викликали 50 \% олійним розчином тетрахлорметану, який вводили підшкірно по 0,8 мл на 100 г маси тіла тварин протягом двох діб із проміж-

ISSN 2312-0967. Фармацевтичний часопис. 2016. № 3 
Фармакологічні дослідження біологічно активних речовин Pharmacological researches of biologically active substances

ком 24 год. Досліджувані екстракти і препарат порівняння "Силібор" вводили за 1 год до і через 2 год після введення отрути в дозі 2,5 мг/0,1 кг маси тіла [8].

Визначення активності трансаміназ АлАТ і АсАТ проводили уніфікованим динітрофенілгідразиновим методом Райтмана - Френкеля за допомогою стандартного набору реактивів фрірми «SIMKO Ltd». В результаті переамінування, яке відбувається під дією ферментів (АлАТ і АсАТ), утворюються піровиноградна і щавлевооцтова кислоти. При додаванні кислотного 2,4 - динітрофенілгідразину ензиматичний процес зупиняється і утворюються гідразони, які в лужному середовищі дають забарвлення, інтенсивність якого пропорційна кількості утворених відповідно піровиноградної та щавлевооцтової кислоти. Забарвлені гідразони мають максим поглинання при довжині хвилі 500 - 560 нм [9, 10].

Дослідження антимікробної активності екстрактів в. лікарської проводили методом дисузії діючих речовин в агар із використанням паперових дисків. Концентрація активної речовини на дисках для екстрактів складала 5 мг [11].

Як універсальне поживне середовище використовували 5 \% кров'яний агар та добові бульйони культур на основі 1 \% цукрового бульйону, в суспензії щільністю 1 млрд мікробних тіл. 1 мл бактеріальної суспензії наносили на поверхню 5 \% кров'яного агару та рівномірно втирали в нього. Посіви інкубували при температурі $37^{\circ} \mathrm{C}$ протягом 24 - 72 год залежно від культурних особливостей досліджуваної культури.

Результати й обговорення. У результаті проведених досліджень визначено протизапальну активність, антимікробну та гепатопротекторну дію водного та водно-спиртового екстрактів трави вербени лікарської.

Визначення гострої токсичності екстрактів трави вербени лікарської. Головним критерієм лікарського препарату $€$ його безпека, перед початком експериментального вивчення протизапальних властивостей екстрактів трави вербени лікарської було проведено визначення їх гострої токсичності. У результаті проведеного дослідження встановле- но, що водний та водно-спиртовий екстракти трави вербени лікарської при одноразовому внутрішньошлунковому введенні у дозі 5000 мг/кг за весь період спостереження у тварин зберігались нормальні ресрлекси, відхилень у поведінці, клінічних симптомів інтоксикації та загибелі тварин не відмічалося, що вказує на відсутність значимої токсичної дії екстрактів вербени лікарської у даній дозі та характеризує їх як відносно нешкідливі лікарські засоби (V клас токсичності - LD 505000 мг/кг) відповідно до загальноприйнятої токсикологічної класифікації речовин [7].

Проведені дослідження протизапальної активності свідчать, що серед всіх досліджуваних екстрактів найвищу протизапальну активність проявляє водно-спиртовий екстракт трави вербени лікарської [7].

Вплив екстрактів оцінювали за здатністю пригнічувати набряк лапки щурів. Протизапальну ефективність розраховували за формулою:

$\%$ пригнічення запалення $=\left(\mathrm{V}_{\mathrm{k}}-\mathrm{V}_{0}\right) / \mathrm{V}_{\mathrm{k}} \cdot 100$,

де $\mathrm{V}_{\mathrm{k}}$ - середнє збільшення об'єму набряклої лапки в контролі;

$\mathrm{V}_{0}$ - середнє збільшення об'єму набряклої лапки у лікованих тварин.

Антиексудативну активність екстрактів вербени лікарської на моделі формалінового запалення лапи щура наведено на рисунку 2 і 3.

3 огляду на результати досліджень, ми спостерігали також імовірне зменшення ступеня розвитку фрормалінового набряку у щурів на фроні введення екстрактів трави вербени лікарської у дозі 0,1 мл/100 г маси тварини. Так, водно-спиртовий екстракт при одноразовому внутрішньошлунковому уведенні білим щурам проявив значний антиексудативний ефект (32,07\%), його виразність була на рівні дії диклосренаку натрію в дозі 8 мг/кг. У групі тварин, яким попередньо вводили водний екстракт трави вербени лікарської, ексудативна активність становила 21,38\%.

Таким чином, за результатами проведених досліджень випробовувані екстракти попереджають роз-

Набряк лапки,

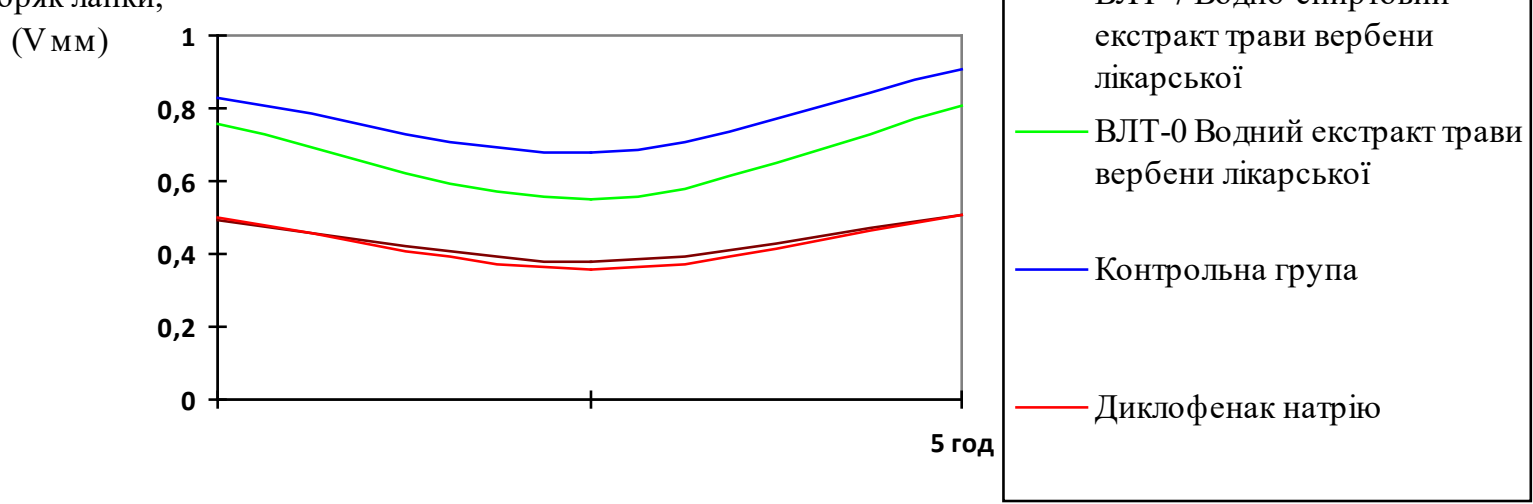

Рис. 2. Вплив досліджуваних екстрактів трави Verbena officinalis L. на розвиток набряку кінцівки щурів.

ISSN 2312-0967. Pharmaceutical review. 2016. № 3 
Фармакологічні дослідження біологічно активних речовин Pharmacological researches of biologically active substances

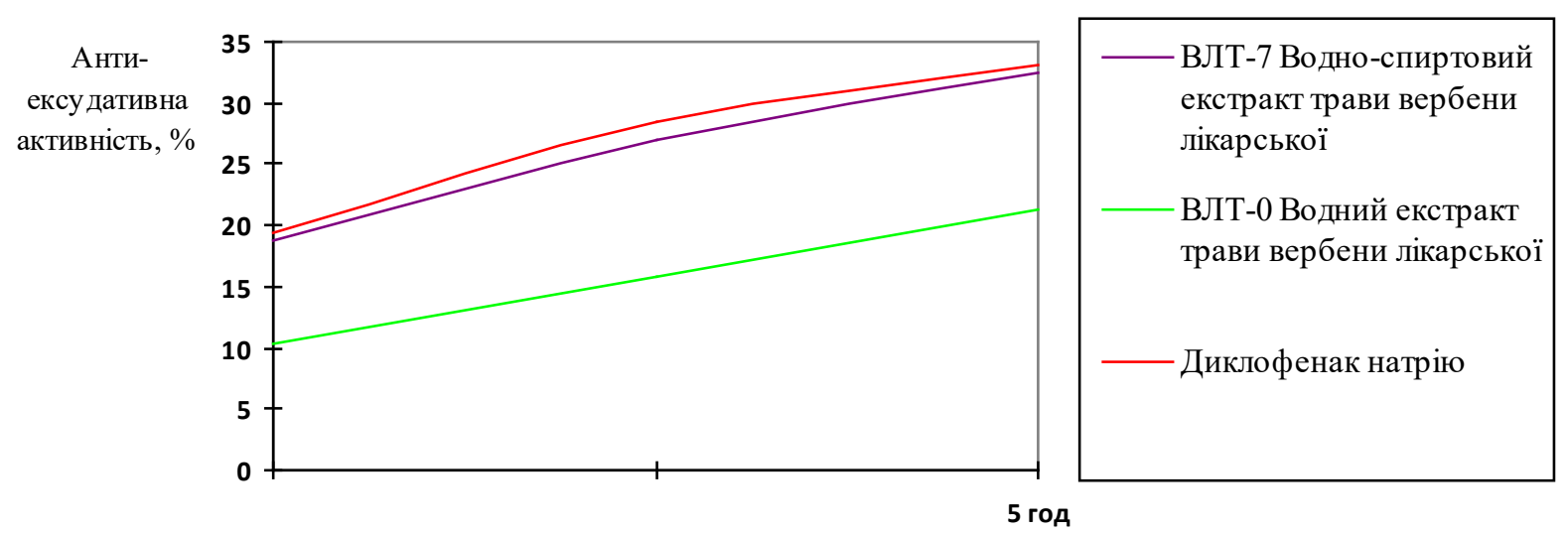

Рис. 3. Антиексудативна активність екстрактів трави Verbena officinalis L.

виток фрормалінового набряку в щурів та проявляють антиексудативну дію. Препарати, що порівнювали, при одноразовому введенні щурам можна розмістити в такому порядку зменшення набрякового екфекту: водно-спиртовий екстракт трави вербени лікарської < диклофренак натрію < водний екстракт трави вербени лікарської.

Вивчення гепатозахисної активності екстрактів трави вербени лікарської проведено на скринінговій моделі ушкодження печінки, яка виникає при введенні тетрахлорметану. Встановлено, що смертність у контрольній групі становила 16,7 \%, в інших групах всі тварини залишались живими до кінця експерименту.

Результати біохімічних показників наведено в таблиці 2.

Результати досліджень (див. табл. 2) показали, що введення тваринам тетрахлорметану призводить до ураження печінки, про що свідчить збільшення активності АлАТ, АсАТ, які є високоспецифічними індикаторами функції мембран гепатоцитів та його органел. Рівень цих показників відповідно зростає в 12 разів порівняно $з$ інтактними тканинами.

Застосування водно-спиртового екстракту трави вербени лікарської при гострому токсичному ураженні печінки значно зменшує токсичну дію тетрахлорметану, забезпечує гепатозахисну дію, яка практично не поступається гепатопротекторній дії препарату "Силібор".
На спосіб одержання екстракту 3 трави вербени лікарської, який проявляє гепатопротекторну дію, одержано патент України на винахід № 46370 u200902291 [12].

Результати антимікробних досліджень свідчать, що екстракти затримують ріст паличкоподібної та кокоподібної мікрофрлори, які часто бувають збудниками госпітальних інфекцій та збудниками вторинного інорікування. Найчутливішими до дії екстрактів $€$ штами стафрілококу, а найбільш стійкими - штами синьогнійної палички.

Оцінку антимікробної активності здійснювали шляхом вимірювання лінійкою зони затримки росту мікроорганізмів (в мм) навколо досліджуваного препарату. Як досліджувані культури використовували Pseudomonas aeruginosa, Esherichia coli, Proteus vulgaris, Staphylococcus aureus, Staphylococcus epidermidis.

Для порівняння бактеріостатичної активності досліджуваних препаратів використовували паперові диски 3 антибіотиками: ампіцилін - 30 мкг/диск, олеандоміцин - 30 мкг/диск.

Результати проведених досліджень представлено на рисунку 4.

Результати проведених досліджень свідчать, що водно-спиртовий екстракт трави вербени лікарської проявляє бактеріостатичну дію проти бактерій Pseudomonas aeruginosa, Esherichia coli, Proteus vulgaris, Staphylococcus aureus ma Staphylococcus epidermidis.

Таблиця 2. Вплив екстрактів трави вербени лікарської на біохімічні та функціональні показники стану печінки

\begin{tabular}{|c|c|c|c|c|c|}
\hline \multirow{2}{*}{$\begin{array}{c}\text { Біохімічні і } \\
\text { гематологічні } \\
\text { показники }\end{array}$} & \multicolumn{5}{|c|}{ Об'єкти дослідження } \\
\hline & ВЛТ-7 & ВЛТ-0 & «Силібор» & $\begin{array}{l}50 \% \text { олійний } \\
\text { розчин } \mathrm{CCl}_{4}\end{array}$ & Інтактні тварини \\
\hline $\begin{array}{c}\text { АлАТ, } \\
\text { мкмоль/год.мл }\end{array}$ & $0,213 \pm 0,0016^{*}$ & $0,336 \pm 0,003 * / * \star$ & $0,220 \pm 0,0024^{*} / * \star$ & $1,36 \pm 0,021^{* / * *}$ & $0,19 \pm 0,011$ \\
\hline $\begin{array}{c}\text { АсАТ, мкмоль/ } \\
\text { год.мл }\end{array}$ & $0,165 \pm 0,0018^{*}$ & $0,210 \pm 0,0018^{\star / * \star}$ & $0,179 \pm 0,0039 * / * \star$ & $1,08 \pm 0,021^{* / * *}$ & $0,16 \pm 0,010$ \\
\hline
\end{tabular}

Примітки: * - достовірно порівняно з інтактними тваринами, $\mathrm{p} \leq 0,05$; ** - достовірно щодо моделі гепатиту, $\mathrm{p} \leq$ 0,05 .

ISSN 2312-0967. Фармацевтичний часопис. 2016. № 3 
Фармакологічні дослідження біологічно активних речовин Pharmacological researches of biologically active substances

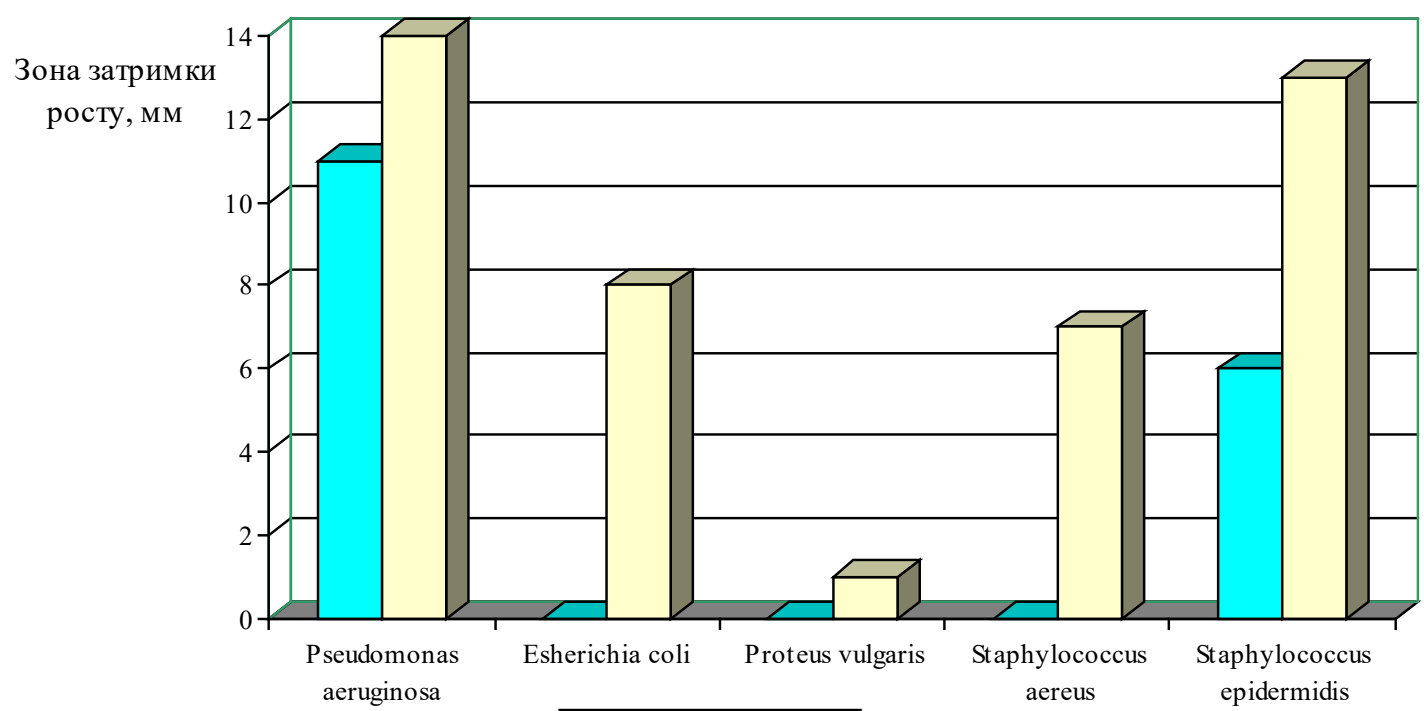

\section{$\square$ ВЛТ-0 $\square$ ВЛТ-7}

Рис. 4. Бактеріостатична дія екстрактів трави вербени лікарської.

Висновки. 1. Одержано водний та водно-спиртовий екстракти трави вербени лікарської.

2. Дослідження гострої токсичності показали, що водні та водно-спиртові екстракти трави вербени лікарської є нетоксичними речовинами при внутрішньошлунковому введенні.

\section{Список літератури}

1. Комендар В. І. Лікарські рослини Карпат В. І. Комендар. - Ужгород : Карпати, 1971. - 246 с.

2. Харчин М. С. Лікарські рослини і їх застосування / М. С. Харчин, А. М. Карамишева, В. І. Сипа, Л. Й. Володарський. - К. : Здоров'я, 1981. - 232 с.

3. Тучак Н. І. Види роду гравілат та вербена перспективні джерела антимікробних засобів / Н. І. Тучак, Н. М. Посацька, Л. М. Грицик, А. Р. Грицик // Сучасні проблеми біології, екології та хімії: міжнар. конфр., присвячена 20-річчю біологічного фракультету ЗНУ, 29 березня - 1 квіт. 2007 р. : зб. матеріалів. Запоріжжя, 2007. - С. $363-365$.

4. Гродзинський А. М. Лікарські рослини: енциклопедичний довідник / за ред. акад. АН УРСР А. М. Гродзинського. - К. : Українська енциклопедія ім. М. П. Бажана, 1990. - С. $124-125$.

5. Ковальова Т. М. Дослідження деяких умов екстрагування біологічно активних речовин при одержанні густого екстракту листя горіха грецького / Т. М. Ковальова, О. Г. Башура, Є. В. Гладух, Н.П.Головко // Фармаком. - 2002. - № 1. - С. 58 - 61 .

6. Пономарев В. Д. Экстрагирование лекарственного сырья / В. Д. Пономарев. - М. : Медицина, 1973. -202 с.
3. Встановлено, що екстракти проявляють антимікробну, протизапальну та гепатопротекторну активність. Водно-спиртовий екстракт вербени лікарської $€$ перспективною субстанцією для розробки препаратів $з$ гепатопротекторною дією.

7. Стефанов О. В. Доклінічні дослідження лікарських засобів: методичні рекомендації / О. В. Стефанов. - К. : Авіцена, 2001. - 528 с.

8. Поздняков В. С. Изменение фрункционального состояния у крыс при воздействии четыреххлористого углерода / В. С. Поздняков, Н. Г. Иванов // Токсикология новых промышленных хим. веществ. - М. : Медицина, 1979. - Вып. 15. - С. 87 - 90.

9. Коробейникова Е. Н. Модифрікація визначення продуктів перекисного окислювання ліпідів у реакції 3 тіобарбітуровою кислотою / Е. Н. Коробейникова // Лабораторное дело. - 1989. - № 7. - С. 8 - 10.

10. Меньшикова В. В. Лабораторні методи дослідження в клініці / под ред. В. В. Меньшикова. - М. : Медицина, 1987. - С. $189-190$.

11. Чорномирдик А. Б. Справочник по применению антибиотиков и других химиотерапевтических препаратов / А. Б. Чорномирдик. - М., 1977. - С. 118 119.

12. Пат. 46370 u200902291. Спосіб одержання екстракту трави вербени лікарської з гепатопротекторною дією / Грицик А. Р., Клименко А. О., Посацька Н. М.; заявл. 16.03.2009; опубл. 25.12.2009, Бюл. № 24. 
Фармакологічні дослідження біологічно активних речовин Pharmacological researches of biologically active substances

\title{
ПОЛУЧЕНИЕ И ИССЛЕДОВАНИЕ СВОЙСТВ ЭКСТРАКТОВ ВЕРБЕНЫ ЛЕКАРСТВЕННОЙ
}

\author{
А. Р. Грицык, Н. Н. Посацкая, А. А. Клименко \\ ГВУЗ «Ивано-Франковский национальный медицинский университет»
}

\begin{abstract}
Резюме: определено острую токсичность водного и водно-спиртового экстрактов травы вербены лекарственной; исследуемые субстанции отнесены к V классу токсичности соединений по классификации Hodge и Sterner (практически нетоксичные вещества - $\mathrm{LD}_{50}>5000$ мг / кг). Доказано противовоспалительную активность водноспиртового экстракта травы вербены лекарственной. Исследовано влияние водного и водно-спиртового экстрактов травы вербены лекарственной на биохимические показатели печени при остром экспериментальном поражении тетрахлорметаном. Экстракты травы вербены лекарственной стабилизируют мембранные структуры клеток печени, что свидетельствует о выраженной гепатопротекторной активности.
\end{abstract}

Ключевые слова: вербена лекарственная, водный и водно-спиртовый экстракты.

\section{OBTAINING AND STUDY OF PROPERTIES OF EXTRACTS VERBENA OFFICINALIS}

\author{
A. R. Hrytsyk, N. M. Posatska, A. O. Klymenko \\ Ivano-Frankivsk National Medical University
}

Summary: it was identified acute toxicity of water and water-alcohol extracts of Verbena officinalis herbs; the investigated substances were assigned to the 5th class of substances' toxicity according to Hodge and Sterner classification (practically non-toxic substances $-\mathrm{LD}_{50}>5000 \mathrm{mg} / \mathrm{kg}$ ). Anti-inflammatory activity of water-alcohol extract of Verbena officinalis herbs was proved. The influence of water and water-alcohol extracts of Verbena officinalis herbs on liver functional and its biochemical parameters in acute experimental lesions with carbon tetrachloride was investigated. Extracts of Verbena officinalis herbs stabilize the membrane structure of the liver cells, which indicates their strong hepatoprotective activity.

Key words: Verbena officinalis, water and water-alcohol extracts. 